\title{
Effects of Supercritical Carbon Dioxide Treatment on Meat Quality and Sensory Evaluation in Soy Sauce and Hot-pepper Paste Marinated Pork
}

\author{
Young Min Choi, Sang Hoon Lee, Jee Hwan Choe, Kyoung Heon Kim, \\ Min Suk Rhee, and Byoung Chul Kim* \\ Division of Food Bioscience and Technology, Korea University, Seoul 136-713, Korea
}

\begin{abstract}
The objective of this study was to investigate the effects of supercritical carbon dioxide $\left(\mathrm{SC}-\mathrm{CO}_{2}\right)$ treatment on meat quality and sensory evaluation of marinated pork. Meat marinated in two traditional Korean marinades, soy sauce and hot-pepper paste, and raw marinated meat were then treated with $7.4,12.2$, or $15.2 \mathrm{MPa} \mathrm{CO}_{2}$ at $31.1^{\circ} \mathrm{C}$ for 10 min. The $\mathrm{SC}-\mathrm{CO}_{2}$ treatments had no effect on the meat $\mathrm{pH}(p>0.05)$ or Warner-Bratzler shear force $(p>0.05)$. There was no significant difference $(p>0.05)$ in the total loss (sum of treatment loss and cooking loss) between the control and $\mathrm{SC}-\mathrm{CO}_{2}$ treated samples at 15.2 $\mathrm{MPa}$ (soy sauce marinated pork: 21.78 vs. $18.97 \%$; hot-pepper marinated pork: 21.61 vs. $18.01 \%$ ). After the $\mathrm{SC}-\mathrm{CO}_{2}$ treatment, lighter surface colors were observed in the treatment samples compared to those of the control samples $(p<$ $0.001)$. However, tasting panelists were unable to distinguish a difference in color or in overall acceptability of the control and treatment $(p>0.05)$. In the case of soy sauce marinated pork, when $\mathrm{SC}-\mathrm{CO}_{2}$ applied at $15.2 \mathrm{MPa}$ and $31.1^{\circ} \mathrm{C}$ for $10 \mathrm{~min}$, treatment samples showed a tenderer meat than the control samples. Therefore, the $\mathrm{SC}-\mathrm{CO}_{2}$ treatment conditions had no adverse effects on the sensory quality characteristics of the marinated meat products.
\end{abstract}

Key words: supercritical carbon dioxide, marinated pork, meat quality, sensory evaluation

\section{Introduction}

Marinated meat is one of the most popular meat products available worldwide. In Korea, the most common marinated meat products are soy sauce or hot-pepper paste marinated, and these products are prepared by marinating the meat in a mixture of soy sauce or hot-pepper paste together with garlic, pears, onion, ginger, sesame seeds, sesame oil, and other seasonings, and then cooking the meat prior to consumption. Recently, the demand for ready-to-cook marinated meat products, especially with adds an ethnic flavor to barbecuing (e.g., Korean BBQ marinated meat products), in many countries has significantly increased (Sloan, 2010; Wong and Kitts, 2002). However, the food safety of these marinated products is difficult to maintain due to the potential for pathogenic contamination and cross-contamination during processing, storage, and distribution, as well as from raw materi-

*Corresponding author: Byoung Chul Kim, Division of Food Bioscience and Technology, Korea University, Seoul 136-713, Korea. Tel: 82-2-3290-3052, Fax: 82-2-925-1970, E-mail: bckim @korea.ac.kr als such as fresh meat and vegetables (Choi et al., 2009a).

Recently, the use of supercritical carbon dioxide (SC$\mathrm{CO}_{2}$ ) has been proposed as a non-thermal food preservation technology that can be used with fresh meat and meat products (Choi et al., 2009b; Garcia-Gonzalez et al., 2007). When fresh meat was treated with $\mathrm{SC}-\mathrm{CO}_{2}$ at 6.05 $\mathrm{MPa}, 45^{\circ} \mathrm{C}$, for $150 \mathrm{~min}$, Brochothrix thermosphacta was reduced by $5.9 \log$ (Erkmen, 2000). In addition, Choi et al. (2009a) reported that by treating the meat with with $\mathrm{SC}-\mathrm{CO}_{2}$ at $14 \mathrm{MPa}, 45^{\circ} \mathrm{C}$, for $40 \mathrm{~min}$ achieved 2.49 and $1.92 \mathrm{Log} \mathrm{CFU} / \mathrm{cm}^{2}$ reductions of Listeria monocytogenes in soy sauce and hot-pepper marinated pork, respectively. However, $\mathrm{SC}-\mathrm{CO}_{2}$ can affect molecular interactions and protein conformation, leading to protein denaturation (Messens et al., 1997) - changes that may influence meat quality. When fresh meat was treated with $\mathrm{SC}-\mathrm{CO}_{2}$, meat quality traits, including muscle $\mathrm{pH}$ and weight loss, were generally unaffected (Choi et al., 2008). While, $\mathrm{SC}-\mathrm{CO}_{2}$ treatment did influence the extent of sarcoplasmic protein denaturation, which is associated with a paler surface color (Choi et al., 2008). Thus, from the perspective of meat quality, $\mathrm{SC}-\mathrm{CO}_{2}$ treatment conditions should be minimized. However, the effect of SC- $\mathrm{CO}_{2}$ treatment on 
improving the safety of meat products, including marinated pork products, under conditions that maintain meat quality have not yet been evaluated. Moreover, for practical use, meat sample sizes and the $\mathrm{SC}-\mathrm{CO}_{2}$ system need to be increased in scale to compare with previous studies (Choi et al., 2008, 2009a, 2009b). The current study was conducted to evaluate the effects of $\mathrm{SC}-\mathrm{CO}_{2}$ treatment on meat quality and sensory evaluations of soy sauce and hot-pepper paste marinated pork products for application on a pilot plant scale.

\section{Materials and Methods}

\section{Sample preparation and treatment}

Twenty-five boneless pork loins, the longissimus dorsi muscle from the 8 to 13th thoracic vertebrae, were obtained from porcine carcass at $24 \mathrm{~h}$ postmortem at a local abattoir, and then transported to the laboratory under refrigerated conditions $\left(4^{\circ} \mathrm{C}\right)$. The entire experiment was repeated five times (five pork loins per each batch). Meat quality characteristics were assessed, and a reddish pink, firm and non-exudative pork loin (lightness of 42 to 50 and drip loss of 2 to 6\%; Choi et al., 2010) were used in this study. The meats were sliced into thirty-two rectangular-shaped pieces $(2.5 \mathrm{~cm}$ thick, each weighing $70 \pm 5 \mathrm{~g}$ ) that were then randomly selected for use in the following experiments to minimize bias.

Two marinades were used (Table 1), one containing soy sauce and one containing hot-pepper paste. The marinades were applied at a 1:1 ratio of pork loin weight to marinade weight, and the pork loins were marinated for $24 \mathrm{~h}$ at $4^{\circ} \mathrm{C}$. The $\mathrm{SC}-\mathrm{CO}_{2}$ treatments were performed in five replicates at pressures of $7.4(7.4-\mathrm{T}), 12.2(12.2-\mathrm{T})$ or

Table 1. Formulas for soy sauce and hot-pepper paste marinades

\begin{tabular}{cccc}
\hline \hline \multicolumn{2}{c}{ Soy sauce marinade (\%) } & \multicolumn{2}{c}{ Hot-pepper paste marinade (\%) } \\
\hline Soy sauce & 14.48 & Hot-pepper paste & 20.00 \\
Water & 43.45 & Water & 37.96 \\
Garlic & 3.64 & Garlic & 3.64 \\
Spring onion & 3.64 & Spring onion & 3.64 \\
Onion & 3.64 & Onion & 3.64 \\
Pear & 7.24 & Pear & 7.24 \\
Ginger & 0.72 & Ginger & 0.72 \\
Sugar & 7.24 & Sugar & 7.24 \\
Starch syrup & 7.24 & Starch syrup & 7.24 \\
Refined rice wine & 7.27 & Refined rice wine & 7.24 \\
Pepper & 0.28 & Pepper & 0.28 \\
Sesame & 0.44 & Sesame & 0.44 \\
Sesame oil & 0.72 & Sesame oil & 0.72 \\
Total & 100.00 & Total & 100.00 \\
\hline
\end{tabular}

15.2 (15.2-T) $\mathrm{MPa}$ at $31.1^{\circ} \mathrm{C}$ for $10 \mathrm{~min}$, using a $\mathrm{SC}-\mathrm{CO}_{2}$ system (Supercritical System, Tharex Co., Korea) that consisted of $2 \times 12$ liter vessels. The first is the high pressure vessel and the rest is the separator. After treatment, the samples were stored at $4^{\circ} \mathrm{C}$ under aseptic conditions and were immediately used for the measurements of meat quality traits and sensory evaluation.

\section{Meat quality traits}

The color of marinated pork was measured with a Minolta chromometer (CR-300, Minolta Camera Co., Japan) and the results were expressed as Commission Internationale de l'Eclairage (CIE, 1978) lightness $\left(L^{*}\right)$, redness $\left(a^{*}\right)$, and yellowness $\left(b^{*}\right)$ values. The average of triplicate measurements was used. The $\mathrm{pH}$ of the seasoned pork was measured using a spear-type electrode (IQ-150 pH meter and PH77-SS probe, IQ Scientific Instruments Inc., CA). The treatment and total weight loss values were expressed as percentages of the initial sample weight. Cooking weight loss was estimated by weighing before and after cooking (Honikel, 1998). The marinated samples were put in thinwalled polyethylene bags and placed in a water bath $\left(80^{\circ} \mathrm{C}\right)$, until the core temperature reached $71^{\circ} \mathrm{C}$. The samples were cooled in ice water for $15 \mathrm{~min}$, and then weighed.

Preparation of cooked pork samples for Warner-Bratzler shear force (WBS) was similar to the procedure for cooking loss. WBS was determined by using an Instron Universal Testing Machine (Model Series IX, Instron Corp., USA) equipped with a Warner-Bratzler shearing device. Eight to ten cores $(1.27 \mathrm{~cm}$ diameter) parallel to the longitudinal orientation of the muscle fibers were taken from each steak. The samples were sheared perpendicular to the long axis of the core.

\section{Sensory evaluation}

A total of twenty steaks (3-dimensional shape of steaks) per each batch were evaluated. A sensory panel consisting of 12 pork-consuming individuals (2040 years of age, 6 females and 6 males) was employed to evaluate the sensory attributes of the cooked pork. The majority of panelists were graduate students, professors and staff members from Korea University. The panelists were trained, and had previous experience in sensory evaluation of various food products including meat products. Before sensory evaluation, all panelists were trained at least 4 weeks (3 times per 1 week) and for up to $1 \mathrm{~h}$ in each training sessions. Training sessions were undertaken as recommended by the American Meat Science Association (AMSA, 1995) and in previously published procedures (Meilgaard et al., 
1991).

Meat samples were roasted in a dry oven (MCS312CF4, Electrolux, Sweden) at $180^{\circ} \mathrm{C}$. The meat was turned every $3 \mathrm{~min}$ and cooked to an internal temperature of $71^{\circ} \mathrm{C}$, which was measured using a thermometer with a handheld probe (TES-1300, TES Electrical Electronic Co., Taiwan). Prior to being presented to the sensory panels, the marinated samples were warmed and maintained in a water bath $\left(54^{\circ} \mathrm{C}\right)$. The samples were then cut into $1 \mathrm{~cm}^{3}$ pieces without surface, placed on white plastic trays, and immediately served to each panelist.

The samples were individually labeled with three-digit random numbers and were served one at a time in a random order. To rate the samples, the panelists used a ninepoint scale with word anchors at each end. The cooked samples were evaluated for color acceptability $(1=$ very unacceptable; $9=$ very acceptable $)$, tenderness $(1=$ very tough; $9=$ very tender $)$, juiciness $(1=$ very dry; $9=$ very juicy), flavor intensity ( $1=$ very weak; $9=$ very strong), and overall acceptability $(1=$ very unacceptable; $9=$ very acceptable). A total of fifteen sessions were conducted with four samples per session. Each session lasted $30 \mathrm{~min}$, with a 5 min interval between the evaluations of each sample. Panelists were served distilled water $\left(30^{\circ} \mathrm{C}\right)$ and salt-free crackers before the first sample and between each sample to cleanse the mouth.

\section{Statistical analysis}

The data were analyzed by ANOVA using the SAS statistical program (SAS Institute, 2008), and differences among the means were compared using Duncan's multiple range test. The entire experiment was replicated five

Table 2. Effects of supercritical carbon dioxide $\left(\mathrm{SC}-\mathrm{CO}_{2}\right)$ treatment at $31.1^{\circ} \mathrm{C}$ for $10 \mathrm{~min}$ on meat quality traits of soy sauce marinated pork products

\begin{tabular}{|c|c|c|c|c|c|}
\hline & \multirow{2}{*}{ Control } & \multicolumn{3}{|c|}{ SC-CO $\mathrm{CO}_{2}$ Pressure } & \multirow{2}{*}{ Level of significance } \\
\hline & & $7.4 \mathrm{MPa}$ & $12.2 \mathrm{MPa}$ & $15.2 \mathrm{MPa}$ & \\
\hline \multicolumn{6}{|c|}{ Quality measurements } \\
\hline Lightness $\left(L^{*}\right)$ & $38.57 \pm 1.98^{\mathrm{c}}$ & $54.52 \pm 1.59^{\mathrm{b}}$ & $56.81 \pm 1.52^{\mathrm{ab}}$ & $58.21 \pm 2.23^{\mathrm{a}}$ & $* * *$ \\
\hline Redness $\left(a^{*}\right)$ & $8.63 \pm 0.29^{\mathrm{a}}$ & $6.52 \pm 0.98^{\mathrm{b}}$ & $6.64 \pm 0.33^{\mathrm{b}}$ & $6.68 \pm 0.70^{\mathrm{b}}$ & $* *$ \\
\hline Yellowness $\left(b^{*}\right)$ & $17.69 \pm 0.42^{b}$ & $17.70 \pm 0.56^{\mathrm{b}}$ & $19.92 \pm 0.86^{\mathrm{a}}$ & $19.83 \pm 0.61^{\mathrm{a}}$ & $* * *$ \\
\hline Meat $\mathrm{pH}$ & $5.56 \pm 0.10$ & $5.71 \pm 0.16$ & $5.64 \pm 0.11$ & $5.60 \pm 0.14$ & NS \\
\hline WBS $(\mathrm{N})$ & $37.57 \pm 6.43^{\mathrm{a}}$ & $38.84 \pm 4.47^{\mathrm{a}}$ & $29.16 \pm 3.78^{\mathrm{ab}}$ & $24.47 \pm 3.54^{\mathrm{b}}$ & $*$ \\
\hline \multicolumn{6}{|l|}{ Weight loss (\%) } \\
\hline Treatment loss & - & $1.06 \pm 0.45$ & $1.16 \pm 0.27$ & $1.80 \pm 0.25$ & NS \\
\hline Cooking loss & $21.78 \pm 3.09$ & $16.23 \pm 2.21$ & $17.47 \pm 4.88$ & $17.67 \pm 3.84$ & NS \\
\hline Total loss & $21.78 \pm 3.09$ & $17.29 \pm 2.65$ & $18.63 \pm 4.46$ & $18.97 \pm 3.24$ & NS \\
\hline
\end{tabular}

Results are expressed as the mean \pm SD.

Levels of significance: $\mathrm{NS}=$ not significant; ${ }^{*} p<0.05,{ }^{* *} p<0.01,{ }^{* * *} p<0.001$.

${ }^{\mathrm{a}-\mathrm{c}}$ Means within a row with different superscripts differ significantly $(p<0.05)$.

WBS, Warner-Bratzler shear force.

Table 3. Effects of supercritical carbon dioxide $\left(\mathrm{SC}-\mathrm{CO}_{2}\right)$ treatment at $31.1^{\circ} \mathrm{C}$ for $10 \mathrm{~min}$ on meat quality traits of hot-pepper marinated pork products

\begin{tabular}{|c|c|c|c|c|c|}
\hline & \multirow{2}{*}{ Control } & \multicolumn{3}{|c|}{ SC- $\mathrm{CO}_{2}$ Pressure } & \multirow{2}{*}{ Level of significance } \\
\hline & & $7.4 \mathrm{MPa}$ & $12.2 \mathrm{MPa}$ & $15.2 \mathrm{MPa}$ & \\
\hline \multicolumn{6}{|c|}{ Quality measurements } \\
\hline Lightness $\left(L^{*}\right)$ & $39.73 \pm 2.07^{\mathrm{c}}$ & $53.29 \pm 1.35^{\mathrm{b}}$ & $57.51 \pm 3.68^{\mathrm{a}}$ & $58.47 \pm 3.55^{\mathrm{a}}$ & $* * *$ \\
\hline Redness $\left(a^{*}\right)$ & $11.15 \pm 0.85^{\mathrm{a}}$ & $7.51 \pm 0.58^{\mathrm{b}}$ & $8.05 \pm 0.57^{\mathrm{b}}$ & $6.92 \pm 1.69^{\mathrm{b}}$ & $* * *$ \\
\hline Yellowness $\left(b^{*}\right)$ & $16.99 \pm 0.94$ & $17.67 \pm 1.56$ & $19.96 \pm 1.91$ & $19.64 \pm 3.01$ & NS \\
\hline Meat $\mathrm{pH}$ & $5.51 \pm 0.03$ & $5.55 \pm 0.11$ & $5.48 \pm 0.17$ & $5.53 \pm 0.14$ & NS \\
\hline WBS $(N)$ & $33.00 \pm 3.40^{\mathrm{a}}$ & $24.57 \pm 4.44^{\mathrm{b}}$ & $22.76 \pm 1.27^{b}$ & $24.03 \pm 2.69^{\mathrm{b}}$ & $*$ \\
\hline \multicolumn{6}{|l|}{ Weight loss (\%) } \\
\hline Treatment loss & - & $1.35 \pm 1.01$ & $1.10 \pm 0.92$ & $2.19 \pm 0.47$ & NS \\
\hline Cooking loss & $21.61 \pm 1.47$ & $17.43 \pm 2.07$ & $16.77 \pm 3.14$ & $15.24 \pm 1.26$ & NS \\
\hline Total loss & $21.61 \pm 1.87$ & $18.78 \pm 1.91$ & $17.87 \pm 2.09$ & $18.01 \pm 2.03$ & NS \\
\hline
\end{tabular}

WBS, Warner-Bratzler shear force.

Results are expressed as the mean \pm SD.

Levels of significance: NS $=$ not significant; $* p<0.05, * * * p<0.001$.

${ }^{\mathrm{a}-\mathrm{c}}$ Means within a row with different superscripts differ significantly $(p<0.05)$. 
times and all determinations were performed in triplicate.

\section{Results and Discussion}

\section{Meat quality traits}

Tables 2 and 3 present the effects of SC- $\mathrm{CO}_{2}$ treatment on the meat quality traits of soy sauce and hot-pepper paste marinated pork products. When marinated pork products were treated with $\mathrm{SC}-\mathrm{CO}_{2}$, all treatment groups exhibited higher lightness values $(p<0.001)$ and lower redness values $(p<0.01)$ compared to the control. In soy sauce marinated pork, the surface of the 15.2-T samples was significantly paler than that of the control or 7.4-T samples (58.21 vs. $54.52, p<0.001)$. In the case of yellowness, no significant differences were observed between the control and 7.4-T samples ( $p>0.05)$. Similarly, all SC$\mathrm{CO}_{2}$ treated hot-pepper paste marinated pork samples appeared significantly lighter than the controls $(p<0.001)$. It has been reported that pressure and temperature combinations in high pressure treatments can influence the extent of protein denaturation (Jimenez Colmenero, 2002). When $\mathrm{SC}-\mathrm{CO}_{2}$ was applied to fresh pork, an increase in denatured proteins was detected by Choi et al. (2008), especially the sarcoplasmic proteins including fructose-6phosphate kinase, creatine kinase, and triosephosphate isomerase, as well as one unknown protein. These denatured sarcoplasmic proteins can influence the color of fresh pork in terms of lightness and redness, and the SC$\mathrm{CO}_{2}$ treatment groups showed the paler surface than the control group (Choi et al., 2008).

Among several reports on meat storage or treatment under various $\mathrm{CO}_{2}$ conditions, Jakonsen and Bertelsen (2002) reported no change in meat $\mathrm{pH}$ following $\mathrm{CO}_{2}$ treatment, while others showed that the $\mathrm{pH}$ decreased with $\mathrm{CO}_{2}$ treatment. In this study, both soy sauce and hot-pepper marinated products did not have significantly different $\mathrm{pH}$ values after the $\mathrm{SC}-\mathrm{CO}_{2}$ treatment from those of the controls $(p>0.05)$. For soy sauce marinated pork, weight losses following $\mathrm{SC}-\mathrm{CO}_{2}$ treatment and cooking were similar in the control samples and in any of the SC$\mathrm{CO}_{2}$ treated samples $(p>0.05)$, and no difference was observed in the weight loss following SC- $\mathrm{CO}_{2}$ treatment at 7.4 MPa and 15.2 MPa for $10 \mathrm{~min}(17.29$ vs. $18.97 \%$, $p>0.05$ ). Similar results were observed for hot-pepper paste marinated pork. The technological aspects and sensory quality traits of a meat depend on the $\mathrm{pH}$ decline: a rapid decline and low $\mathrm{pH}$ causes the denaturation of muscle proteins, especially the extent of myofibrillar protein denaturation affects water-holding capacity (Offer, 1991;
Choi and Kim, 2009). For this reason, fresh meat with lower muscle $\mathrm{pH}$ is associated with higher drip and cooking losses (Kang et al., 2011). However, the extents of myofibrillar protein denaturation as well as muscle $\mathrm{pH}$ of fresh pork were not affected by the $\mathrm{SC}-\mathrm{CO}_{2}$ treatment (Choi et al., 2008). In this study, the $\mathrm{SC}-\mathrm{CO}_{2}$ treatment had no effect on the $\mathrm{pH}$ of soy sauce or hot-pepper marinated pork as well as cooking loss.

Previous studies have reported effects of pressurization on tenderness attributes. The majority of studies showed that the high pressurization is associated with the tenderizing of meat due to structural changes of the myofibrils (Cheftel and Culioli, 1997; MacFarlane, 1973; Schumann et al., 1982; Suzuki et al., 1992). For example, when bovine semitendinosus muscle pressurized to $300 \mathrm{MPa}$ at $10^{\circ} \mathrm{C}$, a decrease in hardness was reported by Suzuki et al. (1992). In other studies examining beef tenderness, however, the application of high pressure at low temperatures $\left(<30^{\circ} \mathrm{C}\right)$ did not have any beneficial effects on coldshortened biceps femoris muscle (Bouton et al., 1977) or on normal or cold-shortened semimembranosus and longissimus muscles (MacFarlane et al., 1981). The $\mathrm{SC}-\mathrm{CO}_{2}$ treatment improved meat tenderness when the samples were treated at a relatively low pressure and temperature $\left(15 \mathrm{MPa}\right.$ and $\left.31.1^{\circ} \mathrm{C}\right)$ with the comparison in the high pressurization treatment (300 MPa). A significantly higher WBS value (less tender) was observed in control samples compared to the 15.2-T soy sauce marinated pork (37.57 vs. $24.47 \mathrm{~N}, p<.05$ ). For the hot-pepper paste marinated pork, all treated samples were significantly tender than those in the control group $(p<0.05)$.

\section{Sensory evaluations}

Table 4 and 5 present the effects of SC- $\mathrm{CO}_{2}$ treatment on the sensory traits of soy sauce and hot-pepper paste marinated pork products. Several studies have reported that the application of pressure causes a gradual change in the surface color of meats, including pork, beef, and tuna (Cheftel and Culioli, 1997; Choi et al., 2008; Hong et al., 2005). The discoloration observed with regard to high pressure processing is related to globin denaturation and the oxidation of ferrous myoglobin to ferric metmyoglobin (Cheftel and Culioli, 1997). Nevertheless, the total color difference due to pressure processing is greatly reduced after cooking. The panelists could not distinguish any surface color differences between the control and SC$\mathrm{CO}_{2}$ treated samples after cooking $(p<0.05)$.

Of all the attributes of palatability of meat and meat products, tenderness is one of the most important traits of 
Table 4. Effects of supercritical carbon dioxide $\left(\mathrm{SC}-\mathrm{CO}_{2}\right)$ treatment at $31.1^{\circ} \mathrm{C}$ for $10 \mathrm{~min}$ on sensory evaluation of soy sauce marinated pork products

\begin{tabular}{cccccc}
\hline \hline & \multirow{2}{*}{ Control } & \multicolumn{3}{c}{ SC-CO $_{2}$ Pressure } & \multirow{2}{*}{ Level of significance } \\
\cline { 3 - 5 } & & $7.4 \mathrm{MPa}$ & $12.2 \mathrm{MPa}$ & $15.2 \mathrm{MPa}$ & NS \\
\hline Color acceptability $^{1}$ & $3.96 \pm 0.72$ & $5.04 \pm 0.97$ & $4.77 \pm 0.99$ & $5.04 \pm 0.51$ & $*$ \\
Tenderness $^{2}$ & $4.38 \pm 0.61^{\mathrm{b}}$ & $5.04 \pm 1.80^{\mathrm{ab}}$ & $5.56 \pm 1.24^{\mathrm{ab}}$ & $6.18 \pm 1.03^{\mathrm{a}}$ & $\mathrm{NS}$ \\
Juiciness $^{3}$ & $3.69 \pm 1.19$ & $4.41 \pm 0.74$ & $4.32 \pm 2.42$ & $3.60 \pm 1.47$ & $\mathrm{NS}$ \\
Flavor intensity $^{4}$ & $5.13 \pm 1.77$ & $4.59 \pm 0.80$ & $4.86 \pm 1.70$ & $3.78 \pm 1.51$ & $\mathrm{NS}$ \\
Overall acceptability $^{1}$ & $3.69 \pm 1.33$ & $5.40 \pm 0.29$ & $4.68 \pm 1.71$ & $4.23 \pm 0.85$ & \\
\hline
\end{tabular}

Results are expressed as the mean \pm SD.

Levels of significance: NS $=$ not significant; ${ }^{*} p<0.05$.

${ }^{a-b}$ Means within a row with different superscripts differ significantly $(p<0.05)$.

${ }^{1}$ Scale: $1=$ very unacceptable; $9=$ very acceptable.

${ }^{2}$ Scale: $1=$ very tough; $9=$ very tender.

${ }^{3}$ Scale: 1 = very dry; $9=$ very juicy.

${ }^{4}$ Scale: 1 = very weak; 9 = very strong.

Table 5. Effects of supercritical carbon dioxide $\left(\mathrm{SC}-\mathrm{CO}_{2}\right)$ treatment at $31.1^{\circ} \mathrm{C}$ for $10 \mathrm{~min}$ on sensory evaluation of hot-pepper marinated pork products

\begin{tabular}{|c|c|c|c|c|c|}
\hline & \multirow{2}{*}{ Control } & \multicolumn{3}{|c|}{ SC- $\mathrm{CO}_{2}$ Pressure } & \multirow{2}{*}{ Level of significance } \\
\hline & & $7.4 \mathrm{MPa}$ & $12.2 \mathrm{MPa}$ & $15.2 \mathrm{MPa}$ & \\
\hline Color acceptability $^{1}$ & $3.96 \pm 1.53$ & $3.87 \pm 1.54$ & $2.70 \pm 1.19$ & $4.32 \pm 0.83$ & NS \\
\hline Tenderness $^{2}$ & $4.80 \pm 0.62$ & $5.00 \pm 1.51$ & $5.16 \pm 0.99$ & $6.38 \pm 1.60$ & NS \\
\hline Juiciness $^{3}$ & $4.23 \pm 0.85$ & $4.32 \pm 1.79$ & $2.61 \pm 0.80$ & $3.96 \pm 1.88$ & NS \\
\hline Flavor intensity ${ }^{4}$ & $4.77 \pm 0.99$ & $4.23 \pm 0.85$ & $4.32 \pm 1.02$ & $3.78 \pm 0.36$ & NS \\
\hline Overall acceptability ${ }^{1}$ & $4.59 \pm 0.80$ & $4.14 \pm 1.62$ & $2.79 \pm 0.74$ & $4.59 \pm 0.80$ & NS \\
\hline
\end{tabular}

Results are expressed as the mean \pm SD.

Level of significance: NS = not significant.

${ }^{1}$ Scale: 1 = very unacceptable; $9=$ very acceptable.

${ }^{2}$ Scale: $1=$ very tough; $9=$ very tender.

${ }^{3}$ Scale: $1=$ very dry; $9=$ very juicy.

${ }^{4}$ Scale: $1=$ very weak; $9=$ very strong.

meat and meat products (Maltin et al., 1998). Generally, the WBS or hardness of texture-profile analysis is positively correlated with the subjective tenderness scores of sensory panelists (Nam et al., 2009). In the case of the soy sauce marinated pork, when $\mathrm{SC}-\mathrm{CO}_{2}$ applied at 15.2 $\mathrm{MPa}$ and $31.1^{\circ} \mathrm{C}$ for $10 \mathrm{~min}$, the tenderness score was higher than the control samples ( 6.18 vs. $4.38, p<0.05)$. However, tenderness scores did not differ between control and $\mathrm{SC}-\mathrm{CO}_{2}$ treated hot-pepper paste marinated pork $(p<0.05)$, even though the WBS values of $\mathrm{SC}-\mathrm{CO}_{2}$ treated samples were significantly lower than those of the control. In case of other eating quality attributes including juiciness and flavor intensity, there were no significant differences between the control and the treatments.

\section{Conclusion}

In this study, $\mathrm{SC}-\mathrm{CO}_{2}$ treatment did not have adverse effects on the meat quality traits of soy sauce or hot-pepper paste marinated pork products, with the exception of lightening the color of the meat. However, panelists did not distinguish color changes or differences in the overall acceptability of the soy sauce or hot-pepper paste marinated products after $\mathrm{SC}-\mathrm{CO}_{2}$ treatment and cooking. In the case of soy sauce marinated pork, when $\mathrm{SC}-\mathrm{CO}_{2}$ applied at $15.2 \mathrm{MPa}$ and $31.1^{\circ} \mathrm{C}$ for $10 \mathrm{~min}$, treatment samples showed a tenderer meat than the control samples. Overall, these results suggested that $\mathrm{SC}-\mathrm{CO}_{2}$ treatment is useful in the meat industry to increase the microbial safety of marinated meat products without defects of meat quality.

\section{Acknowledgements}

This research was funded by the Korea Institute of Planning and Evaluation for Technology of Food, Agriculture, Forestry, and Fisheries. The authors thank the Korea University Food Safety Center for use of their equipment and facilities. 


\section{References}

1. AMSA. (1995) Research Guidelines for Cookery, Sensory Evaluation, and Instrumental Tenderness Measurements of Fresh Meat. American Meat Science Assoc., Chicago, IL.

2. Bouton, P. E., Ford, A. L., Harris, P. V., Macfarlane, J. J., and O'SHEA, J. M. (1977) Pressure-heat treatment of postrigor muscle: Effects on tenderness. J. Food Sci. 42, 132-135.

3. Cheftel, J. C. and Culioli, J. (1997) Effects of high pressure on meat: A review. Meat Sci. 46, 211-236.

4. Choi, Y. M. and Kim, B. C. (2009) Muscle fiber characteristics, myofibrillar protein isoforms, and meat quality. Livest. Sci. 122, 105-118.

5. Choi, Y. M., Bae, Y. Y., Kim, B. C., Kim, K. H., and Rhee, M. S. (2009a) Effects of supercritical carbon dioxide treatment against generic Escherichia coli, Listeria monocytogenes, Salmonella Typhimurium, and E. coli $\mathrm{O} 157: \mathrm{H} 7$ in marinades and marinated pork. Meat Sci. 82, 419-424.

6. Choi, Y. M., Kim, O. Y., Kim, K. H., Kim, B. C., and Rhee, M. S. (2009b) Combined effect of organic acids and supercritical carbon dioxide treatments against nonpathogenic Escherichia coli, Listeria monocytogenes, Salmonella Typhimurium and E. coli O157:H7 in fresh pork. Lett. Appl. Microbiol. 49, 510-515.

7. Choi, Y. M., Lee, S. H., Choe, J. H., Rhee, M. S., Lee, S. K., and Kim, B. C. (2010) Protein solubility is related to myosin isoforms, muscle fiber types, meat quality traits, and postmortem protein changes in porcine longissimus dorsi muscle. Livest. Sci. 127, 183-191.

8. Choi, Y. M., Ryu, Y. C., Lee, S. H., Go, G. W., Shin, H. G., Kim, K. H., Rhee, M. S., and Kim, B. C. (2008) Effects of supercritical carbon dioxide treatment for sterilization purpose on meat quality of porcine longissimus dorsi muscle. LWT-Food Sci. Technol. 41, 317-322.

9. Commission International De L'ecairage. (1978) Recommendations on uniform color spaces - Color differences equations, Psychrometric color terms. Supplement No. 2, CIE Publication No. 15 (E1.3.1).

10. Erkimen, O. (2000) Antimicrobial effects of pressurised carbon dioxide on Brochothrix thermosphacta in broth and foods. J. Sci. Food Agric. 80, 1365-1370.

11. Garcia-Gonzalez, L., Geeraerd, A. H., Spilimbergo, S., Elst, K., Van Ginneken, L., Debevere, J., Van Impe, J. F., and Devlieghere, F. (2007) High pressure carbon dioxide inactivation of microorganisms in foods: The past, the present and future. Int. J. Food Microbiol. 117, 1-28.

12. Hong, G. P., Park, S. H., Kim, J. Y., Lee, S. K., and Min, S. K. (2005) Effects of time-dependent high-pressure treatment on physico-chemical properties of pork. Food Sci. Biotechnol. 14, 808-812.

13. Honikel, K. O. (1998) Reference methods for the assessment of physical characteristics of meat. Meat Sci. 49, 447-457.

14. Jakobsen, M. and Bertelsen, G. (2002) The use of $\mathrm{CO}_{2}$ in pac- kaging of fresh red meats and its effect on chemical quality changes in the meat: A review. J. Muscle Foods 13, 143-168.

15. Jimenez Colmenero, F. (2002) Muscle protein gelation by combined use of high pressure/ temperature. Trends Food Sci. Tech. 13, 22-30.

16. Kang, Y. K., Choi, Y. M., Lee, S. H., Choe, J. H., Hong, K. C., and Kim, B. C. (2011) Effects of myosin heavy chain isoforms on meat quality, fatty acid composition, and sensory evaluation in Berkshire pigs. Meat Sci. 89, 384-389.

17. MacFarlane, J. J. (1973) Pre-rigor pressurization of muscle: Effects on $\mathrm{pH}$, shear value and taste panel assessment. J. Food Sci. 38, 294-298.

18. MacFarlane, J. J., Mckenzie, I. J., Turner, R. H., and Jones, P. N. (1981) Pressure treatment of meat: Effects on thermal transitions and shear values. Meat Sci. 5, 307-317.

19. Maltin, C. A., Sinclair, H. L., Warriss, P. D., Grant, C. M., Porter, A. D., Delday, M. I., and Warkup, C. C. (1998) The effects of age at slaughter, genotype and finishing system on the biochemical properties, muscle fibre type characteristics and eating quality of bull beef from suckled calves. Anim. Sci. 66, 341-348.

20. Meilgaard, M., Civille, G. V., and Carr, B. T. (1991) Affective tests: Consumer tests and in-house panel acceptance tests. In: Sensory evaluation techniques. Meilgaard, M., Civille, G. V., and Carr, B. T. (eds).Boca Raton, CRC Press Inc., FL, pp. 211-222.

21. Messens, W., Van Camp, J., and Huyghebaert, A. (1997) The use of high pressure to modify the functionality of food proteins. Trends Food Sci. Tech. 8, 107-112.

22. Nam, Y. J., Choi, Y. M., Lee, S. H., Choe, J. H., Jeong, D. W., Kim, Y. Y., and Kim, B. C. (2009) Sensory evaluations of porcine longissimus dorsi muscle: relationships with postmortem meat quality traits and muscle fiber characteristics. Meat Sci. 83, 307-311.

23. Offer, G. (1991) Modelling of the formation of pale, soft, and exudative meat: effects of chilling regime and rate and extent of glycolysis. Meat Sci. 30, 157-184.

24. SAS. (2008) SAS/STAT Software for PC. Release 9.2, SAS Institute Inc., Cary, NC, USA.

25. Schumann, M. S., Kennick, W. H., and Rock, D. F. (1982) Effect of hot boning and pre-rigor pressurization of beef on factors of economic importance. J. Food Sci. 38, 864-866.

26. Sloan, A. E. (2010) Top 10 functional food trends. Food Technol. 64, 23-41.

27. Suzuki, A., Kim, K., Homma, N., Ikeuchi, Y., and Saito, M. (1992) Acceleration of meat conditioning by high pressure treatment. In: High Pressure and Biotechnology. Balny, C., Hayashi, R., Heremans, K., and Masson, P. (eds) Institut Natl De LA Sante., Paris, France, pp. 219-227.

28. Wong, P. Y. Y. and Kitts, D. D. (2002) The effects of herbal pre-seasoning on microbial and oxidative changes in irradiated beef steaks. Food Chem. 76, 197-205.

(Received 2013.6.5/Revised 2013.8.29/Accepted 2013.9.4) 